\title{
The Narcissism of Sue Bridehead in Jude the Obscure
}

\author{
Nan Zhao \\ Foreign Language Department, \\ NCIAE \\ Langfang, Hebei Province, China \\ renzhiyi@126.com
}

\author{
Zhiyi Ren \\ Foreign Language Department \\ NCIAE \\ Langfang, Hebei Province, China renzhiyi@126.com \\ renzhiyi@126.com
}

\begin{abstract}
In Jude the Obscure, Sue Bridehead is an image of complex, puzzling unstateable and knowledgeable Victorian woman. She has a particular narcissistic psyche which Hardy deliberately depicts. By the comparison between his vivid and acute depiction and Freud's analysis on the narcissism, we can probe into Hardy's sensitive insights into the psychology of human being.
\end{abstract}

\section{Keywords- narcissism; complex; masochism; Sue Bridehead}

\section{INTRODUCTION}

The Characterization of Sue is one of Hardy's most remarkable achievements. With her, Hardy is exploring further aspects of personality in human being. Sue is an impressive and inexplicable heroine in all his novels. Hardy incorporates the "puzzling" and "unstateable" qualities of Sue Bridehead into the novel. In the letter to Edmund Grosse in 1895, Hardy wrote "Sue is a type of woman which has always had an attraction for me, but the difficulty of drawing the type has kept me from attempting it till now". (Norman, 347) It indicates that Hardy has the great interest in Sue's inner world. In Jude the Obscure, Hardy with great psychological insight and sympathy is carefully building up a picture of a personality precariously balanced on the edge of sanity. This is Sue's personality; in fact Hardy attempts to create the type all through, while Sue is the culmination among his Characters. She is the most complex, as Hardy wrote to Gross, exceptionally difficult to depict. However, the characteristic he depicts is always obscure, so that many scholars could not understand his insight in Sue's real psychology until Freud has zest for this type of woman like Sue. Many of the qualities which Hardy portrays in Sue were found also by Freud in the neurotic women he analyzed. Sue and the "narcissistic" women usually experienced and inflicted the similar joy and anguish.

\section{THE DEMONSTRATION OF SUE'S NARCISSISTIC PYSCHE}

Sue Bridehead in Jude the obscure is a narcissistic Victorian woman and similar to those women whose needs do not "lie in the direction of loving but of being loved". (On Narcissism 89) When she tries to ask Jude quote from "Epipsychidion", and eventually recites the lines herself, applying them to herself and saying that they are "too flattering”. (Hardy 247) Freud's expressions "They are plainly seeking themselves as love objects”(On Narcissism 88) have the similar meaning with Sue's strange behavior pattern. "Strictly speaking, it is only themselves that such women love with an intensity comparable to that of a man's love for them”. (On Narcissism 89) This is the interpretation of narcissism from Freud; in fact, it is also an account of Sue's reflection of her inner psyche. She tells Jude:

Your wickedness was only the natural man's desire to possess the woman. Mine was not the reciprocal wish till envy stimulated me oust Arabella. I had thought in charity to let you approach me- that it was damnably selfish of me to torture you as I did my other friend. But I shouldn't have given way if you hadn't broken me down by making me fear you would go back to her.... At first, I did not love you Jude; that I own. When I first knew you, I merely wanted you to love me. .....and so I got to love you Jude,..., it began in the selfish and cruel wish to make your heart ache for me without letting mine ache for you. (Hardy 356-57)

This is the self-analysis from Sue. Actually it is strikingly accurate and appropriate for her particular narcissistic psyche. Firstly, her attitude towards men is cool and she causes her lovers "doubts of her love and complaints of her enigmatic nature”. (Freud, On Narcissism 88) Her inborn craving demands Jude, phillotson, and the undergraduate to love her, but she would never reciprocate it, because she "harbors an exaggerated sense of his own self-importance and uniqueness". (narcissism, Columbia Encyclopedia) Although she admits that she loves Jude and goes to bed with him, it is Arabella's appearance that forces her to do so. Secondly, to some degree, "narcissism has the significance of a perversion that has absorbed the whole of the subject's sexual life". (Freud, Standard edition 73) Actually, Sue understands herself through her self-analysis on her sadistic impulses (Sue uses the word "torture") which may seem incompatible with the image of modern and intellectual Sue at first sight. But I think it is another example of Hardy's insight into psychological complexities.

Freud maintains that masochism is an element in narcissism since "masochism is actually sadism turned round upon the subject's own ego". (Standard edition 127) Therefore, she continually tortures her lovers. She tells Jude that for fifteen months she had lived with a Christminster undergraduate who became ill and died as a result of her enigmatic nature and inaccessibility; she marries Phillotson in spite of Jude's love for her; and after marriage she can not live with him as a husband. Similarly, Sue tells Jude she loves him. While Jude wishes to kiss her "just once or so", she says "I've let you kiss me, and that tells enough." "Don't be a greedy boy". (Hardy 242) According to Freud, the normal and healthy love generally relies on the combination of two feelings. One is the soft and unalterable love; the 
other one is the sensual desire. (Psychology of Love, N. pag.) We may refer from the above evidences that Sue is a special woman, and a "frigid woman" from Freud's viewpoint. While she says, "People say I must be cold-natured---sexless---on account of it. But I won't have it!"(Hardy 148) Her words suggest she is not frigid as her male company and Arebella comment. As for Sue's psychological contradiction, Freud explains that a person who has a narcissistic tendency usually "treats his own body in the same way in which the body of a sexual object is ordinarily treated". (On Narcissism 73) And the embodiment of Sue's narcissism is her attitude to sex, and is evidenced by Phillotson, Jude, herself or the narrator. "The slim little wife or a husband whose person was disagreeable to her, the ethereal, fine-nerved, sensitive girl, quite unfitted by temperament and instinct to fulfill the conditions of the matrimonial relation with Philotson”. (Hardy 219) While Jude felt much depressed, "she seemed to get further and further away from him with her strange ways and curiousness of gender”, (148) and later Jude says to her, "you are absolutely the most ethereal, least sensual woman I ever knew to exist without inhuman sexlessness". (348) Due to her psychological narcissism, Sue makes her male companies suffer the pain from her sadism.

Later, she shift the torture on to herself for the guilt of having caused her partners pain, she continually punishes herself. First of all, she marries Mr. phillotson whom she does not love at all. She says to Jude, “I don't like him-it is a torture to me- live with him as husband". (213) She marries Phillotson not merely to deliberately hurt Jude but to punish herself for having made her husband suffer. And then she marries him a second time, when her self-punishing has become almost hysterical, especially after the death of her children. Her sadism turns to masochism completely. Jude repeatedly feels that her intellect has been destroyed since the deaths of the children and "her once keen vision was dimmed”. (364) Actually, her reasoning faculty is overwhelmed by the bereavement, and her inner psyche becomes unbalanced and disturbed. She punishes herself by scrubbing the stairs "since eight" and simultaneously washes away her guilt. She tortures herself by exhausting her energy. Furthermore, Sue also punishes herself in an extreme way. Firstly, she admitted to any "grossness" in her. When she will never see Jude again, she says "I love him-O, grossly". (399) Sue is a woman who usually oppresses her sexual consciousness. So it must be miserable to admit this. Secondly, she decided to fulfill her duty as the wife and does the "penance". She forces herself to suffer the intense painshuddering and clenching her teeth. "Sue sees her decision as a way of enabling herself to cope with her overwhelming sense of guilt, ostensibly guilt because she left Phillotson in the first place, then guilt because she has kissed Jude, and probably above all, guilt because of the grossness of her feeling for him". (Sumner 179) Actually, it is the utmost that she can do to torture herself. As far as Sue is concerned, her self-punishment has hit the peak of her masochism.

Her desire to punish herself is understandable, however unreasonable. Freud believes that masochism is one embodiment of narcissism. As for her strange behaviors, Freud has an interpretation which is different from Sue's explanation of her motives but has a close similarity with Hardy's characterization of Sue's personality. Freud says: Of the many symptomatic pictures in which obsessional neurosis appears, the most important turn out to be those provoked by the pressure of excessively strong sadistic sexual impulses (perverse therefore in their aim). (General Theory 309)

Here Freud is talking about people who find a substitute for the sexual act, but Sue's "prostituting" herself to Phillotson is just as much an "abnormal method of sexual excitation" (General Theory 309) as any other inclination. In fact, after the death of her children, she left Jude for remarrying Phillotson; her self-containment has collapsed and her strong sadistic sexual impulse could not find a normal method to abreact. Therefore, she chooses the extreme way to torment herself, and even forces herself on a hesitant man, while shrinking, clenching her teeth, and managing to utter no cry. I think Sue's tripartite model of the mind has been disturbed severely, and they could not work harmoniously. As Freud says, "it seems that an accumulation of narcissistic libido beyond a certain amount is not to be tolerated.”(General Theory 421) Therefore, she admitted "I love him-O, grossly!”(Hardy 339) and went back to Phillotson to share his bed in the end. The self-love triumphs in Sue when she first knows Jude; while self-hatred triumphs in the end. "There was no more Sue. Body, soul, and spirit, she annihilated herself”. (Lawrence, Selected 72)

\section{THE REASONS OF HER NARCISSISM}

The above analysis reveals Sue's narcissistic complexity. So what leads the lovely and charming Sue to have such a personality? Here we have to trace back to her childhood experiences. Sue's childhood is an unhappy one, suggested by Aunt Drusilla when she says Sue is of the "inimical branch of the family". (Hardy 76) When she was young, the fact that her parents divorced affected her negative attitude to the marriage and the relationship between wife and husband. Here Freud argues, "Quarrels between parents and unhappy marital relations between the same determine the severest predispositions for disturbed sexual development or neurotic disease in the children". (Three Contributions 75) Sue tells Jude that she is "the Ishmaelites", (Hardy, 138) which suggests she is abandoned by her father in her infancy. And she is also taught to hate her mother by her father. When Sue grows up, she is hard to adjust to the marriage life, and even fear about it. Thus, she has somewhat tendency to Narcissism by degrees. Therefore, she lives with three men in an ostensibly sexless and fraternal intimacy, and she leads them on and then rejects them, and then does penance for the suffering she thus has caused.

As for the reason of the narcissism, Freud makes a theoretical analysis. He maintains that the individual, during the first five years of life, progresses through several developmental stages that affected personality. Applying a broad definition of sexuality, he calls these periods psychosexual stages. At each stage, the pleasure-seeking impulses of the id focus on, and derive pleasure from, a particular area of the body and some activities connected with that area. Freud calls the first year of life the oral stage of psychosexual development in which infants derive pleasure from nursing and sucking. The second stage is the anal stage with imposed control in the form of their toilet training. At the third stage from about age 3 to age 6, children focus on their genitals. Freud regards this stage as the most important period to affect one's personality. (Three Contribution 34-46) The children observe the differences between males and females and may direct their awakening sexual impulses toward the parent of the opposite sex. It is at 
this stage that children have to resolve the Oedipus and Electra complexes. We learn that Sue lived with her father after the departure of her parents, and "she was brought up by her father to hate her mother's family". (Hardy 110) Although he never actually makes an appearance in Jude the Obscure, we can infer that Sue must have had the Electra complex. According to Freud, if the complex can not be resolved, one's personality and psychology will develop unhealthily.

Freud's explanation demonstrates why Sue has a distaste on sexuality. Simultaneously, Freud puts forwards that infantile sexual impulse can function as the ego libido or narcissistic ego-libido; and may have a fixation of libido after growing up, namely sexual psychology is fixed at "narcissistic stage". (Three Contribution 69-74) Literally, the fixation makes the mature libido back to the infantile sexual experience, thus sexual impulse rushes at the self instead of the opposite sex. In short, Sue's morbid and narcissistic character stems from her childhood experience and the fixation of libido after growing up. She also says, "I cave to get back to the life of my infancy and its freedom". (Hardy 138) It is another evidence that Hardy has been aware that childhood experience can have great influence on the development of one's psychology.

Sue's narcissistic and morbid character results in her indifference or detestation to the opposite sex, and helps to develop the character of the psychological elusiveness of her double nature. It also illustrates that Hardy's creative imagination takes to their furthest point his exploration of complex, psychologically disturbed personalities.

Hardy is aware of that human beings are ultimately unknowable. In Jude the Obscure, Hardy shows the elusive psychological characteristic of Sue and in particular focuses on her uncertainty strongly. It is really hard to define or explain her. She has "indefinable charm", (369) and "liquid untranslatable eyes" (88) which make her impossible to be understood completely. Other characters continually feel puzzled about her. Jude confirms this: "her conduct was one lovely conundrum to him”. (135) Phillotson regards her "puzzling” and "unstable" and says, "her exact feeling for him [Jude] is a riddle to me-and to him, too, I think-possibly to herself”. (231) They can never understand and outguess her. In fact, Sue's thought is like a labyrinth of contradictions. She is a woman with a twentieth-century mind controlled by a nineteenth century view of self. (Gary 50) For example, she always considers herself as a liberated thinker, a neopagan, a reader of Swinburne, Gibbon, Mill, and other heterodox writers, yet she turns out to be like Chrisminster, a prisoner of convention, and a deadlock between the old world and the new.

Therefore, when Jude begins to contact with Sue at the very beginning, he thinks that Sue is an unconventional girl. However, later he doubts his judgment and regards her "as enslaved to the social code as any woman I know". (243) Sue is an educated and intelligent woman. So she always tries to challenge the patriarchy which governs the society of that time to demonstrate her novelty, and holds strange ideas in terms of the contemporary. Simultaneously, she is not likely to escape from the reality and change her surrounding social environment. In fact, this conflict plays a partial role in her contradictory psychological characteristic and words or behaviours. Sue sketches Arebella as "flesh, coarse woman", "low-passioned woman" and despises her. Her description illustrates her unconventional assessment standard. However, on one occasion, she argues that Jude should not go to give a hand to Arebella because she is not her wife anymore. Here, she betrays herself at once. Likewise, she marries Phillotson, but the marriage is not consummated; she elopes with Jude, but refuses to sleep with him; she even can talks about sex with her friends. All this evidences can show that she quite differs from the traditional women at that time. Nevertheless, under some circumstances, Sue holds the same feeling as her contemporary woman. For instance, she feels embarrassed when Jude enters the room where her wet clothes are hanging and she is also not comfortable after being excluded by the school and when feeling jealous of Arebella. Later, Jude accuses her of being "enslaved to the social code" and she replies, "Not mentally. But I haven't the courage of my views". (243) Her words show the split between feeling and reason, thus explores Sue's contradictory and complicated personality.

\section{CONCLUSION}

In these ways, Hardy creates a living, changing, incompletely comprehensible figure. He avoids the effect of a too precise clinical analysis so that there is no suggestion of a case history in spite of the mass of clinical psychological materials embedded in the novel. Though he explores her psychological complexities in great depth, he deliberately avoids giving the impression that she is a finite being whose personality can be wholly explained in words. The alteration of "unpredictable" in the first edition to "unstateable" in later editions confirms that Hardy wanted to emphasize that however minutely he analyses the character, there always remains an area of being which is unknowable. (Sumner 183) Actually, Hardy has succeeded in conveying the indefinable and unconscious aspects of Sue's personality, Therefore, by establishing so vividly Sue's elusiveness and contradictoriness Hardy explores his further psychological insight. By the characterization of Sue, Hardy demonstrates his perception on this point and implies the relationship among elusiveness, narcissism and the growing experiences.

\section{REFERENCES}

[1] Adelman, Gary. Jude the obscure: A Paradise of Despair. New York: Thayne Publishers, 1992.

[2] Freud, Sigmund. On Narcissism. Standard Edition: 14:69-102. London: Hogarth Press, 1957.

[3] The Psychology of Love. Trans. Shaun Whiteside. London: Penguin, 2007.

[4] The Standard Edition of the Complete Psychological Works of Sigmund Freud, Vol.14. Strachey James, and Anna Freud, ed. London: Hogarth Press, 1963.

[5] General Theory of the Neuroses. Standard Edition: 16:234-463. London: Hogarth Press, 1963.

[6] Three Contributions to the Theory of Sex. Trans. Abraham Arden Brill. New York: Journal of Nervous and Mental Disease Pub. Co., 1910

[7] Hardy, Thomas. Jude the Obscure. London: Signet Classic, 1961.

[8] Lawrence, David Herbert \& Herbert, Michael. D.H. Lawrence Selected Critical Writings. Oxford: Oxford University Press, 1998.

[9] Norman Page, ed. Thomas Hardy: The Writer and His background. London: Bell \&Hyman Limited, 1980. 